institutions recruiting internationally, public-private partnerships (for example, U.K. and Australian universities operating with local partners in Singapore and Malaysia and recruiting international students to those countries), and institutions operating across national borders and sometimes with multinational public-sector ownership. Here, the group agreed to keep to its original definition of an international student: a person who physically moves from his or her place of residence for the purposes of study, regardless of the "ownership" of that place of study.

\section{Next Steps}

Apart from a series of tangible outcomes of the conference-for example, a document outlining the various decisions about definitions and plans to expand participation and update the data via a website to be launched in late 2004-there was one less tangible but important outcome: the message that no single organization "owns" Project Atlas, that everyone has a vested interest in its success and that it is the product of a collaborative effort with many avenues for contribution. More than anything else, this message was foremost in the building of a collective enterprise of data collection and dissemination, vital for the development of a global understanding of international student mobility.

(Note: the Atlas of Student Mobility may be purchased through IIE Books for U.S.\$49; see www.iiebooks.org).

\section{Where Did All the International Students Go?}

\section{Liz Reisberg}

Liz Reisberg is executive director of the MBA Tour. Address: The MBA Tour, 20 Shawnee Road, Arlington, MA 02476, USA. E-mail: liz@thembatour.com.

$\mathrm{B}$ y early 2004 it became apparent that the rate of international applications to graduate programs in the United States, Europe, and Canada had dropped alarmingly. International applications are down by 20 to 30 percent at most universities. The most precipitous decline has been in applications from China. Admissions officers had become complacent about the seemingly endless supply of talent from China and were stunned when the number of Chinese taking graduate admissions tests (both the GRE and GMAT) had dropped by half. Although speculation is widespread as to what caused this discouraging trend, no definitive answer has yet been found.
Changes in visa policy have created new impediments for individuals planning to study in the United States. The U.S. government now requires interviews for everyone applying for a U.S. visa, regardless of the purpose of the visit. Of course, without authorization for extended hours, additional staff, or budget increases, a backlog of requests for appointments was inevitable. The lack of training for interviewers means that the interview experience and outcome vary considerably. A new, nonrefundable $\$ 100$ price tag has been instated for a visa application and an additional $\$ 100$ fee for being registered in the Student and Exchange Visitor Information System (SEVIS) once a student visa is approved.

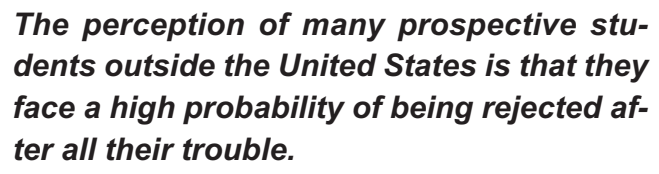

The perception of many prospective students outside the United States is that they face a high probability of being rejected after all their trouble, although it is not clear whether this is actually the case or not. Rumors abound, but it seems that while the rejection rate may be higher for nondegree study (e.g., English as a Second Language programs), most students with admission to a degree program and a well-articulated plan for when they will still graduate seem to be getting visas. Certain countries may be the victims of political backlash. Students from Moslem countries will certainly have a tougher time getting visas to study in the United States.

It is not only U.S. visas that presents new challenges. Since last year when three Chinese students were charged with murder, the Japanese have denied 73 percent of the Chinese applicants for student visas. Visa applications to study in Europe and Canada have a better probability of being approved, but even there the process and screening are more elaborate and take longer. Students are obliged to enter the admissions cycle earlier, hoping for a prompt decision so that they can begin the visa process as soon as possible. Given the prolonged process, until orientation week universities may not know how many of their foreign students will succeed in obtaining visas.

The question being asked around the world is whether it is worth the trouble of applying to study abroad as well as enduring the indignities and costs of the visa process. For an increasing number of individuals the answer is now "no." Furthermore, there are a growing number of alternatives at home. 


\section{Studying at Home}

Many students have decided not to go abroad at all. Globalization seems to have created new options for people who decide to study at home. New private universities have opened up throughout the world, many located in countries that were historically the primary "exporters" of students. While some new institutions are little more than storefronts, others boast internationally educated faculty and infrastructure hitherto unknown at many traditional universities. Exchanges of students and faculty and joint-degree programs with top internationally recognized universities motivate many of these universities to pursue international standards of quality. Furthermore, with more public and private money being invested in higher education in countries like China, programs at home compete handily with programs abroad. Today, students are as likely to aspire to earning a graduate degree from Tsinghua University and other top Chinese universities as a degree from abroad.

Seeing the international market starting to dissipate and the rise of new off-shore economic opportunities, many universities in North America and Europe have launched operations overseas. These endeavors can be as simple as an executive education program or as elaborate as an entire campus. It is impossible to document all of the international degrees being awarded overseas today. Rutgers, Fordham, the University of Southern California, MIT (to name a few) are offering degree programs in China in conjunction with top local universities. INSEAD, in France, has created an entire campus in Singapore. This offshore activity inevitably contributes to the declining numbers of students leaving home to study.

\section{New Destinations}

It is now more common for students, particularly in Asia, to look more seriously at opportunities in Australia rather than the United States or Europe. With the rising cost of the dollar and the euro, Australia represents (not only) a more welcoming destination but a better value. Australia experienced a 16.5 percent increase in the number of foreign students in 2003, attracting students who probably would have chosen a different destination in the past.

Many aspiring graduate students hope not only to earn an international degree but to acquire work

\section{Internet Resources}

Visit our website for downloadable back issues of International Higher Education and other publications and resources at http:/ / www.bc.edu/cihe/. experience while abroad to improve their job prospects when they return home. Although the United States allows foreign students to remain for 12 months of practical training, extended work permission is more elusive since the current Bush administration reduced the number of H1Bs (visas allowing nonresident aliens to work in the United States) awarded annually by twothirds. Canada has become a more attractive destination for students who wish to remain abroad to work for several years after graduating, as foreign talent is welcomed into the Canadian work force. The United Kingdom has announced new initiatives to integrate more international professionals into their job market as well. Universities in countries that offer the possibility of postgraduation employment will undoubtedly be very attractive.

\section{Universities in countries that offer the pos- sibility of postgraduation employment will undoubtedly be very attractive.}

\section{The Degree as a Commodity}

Finally, there is the issue of "return on investment." As painful as it sometimes is to concede this, academic credentials are often seen as a tradable commodity. Students often went abroad because of the economic advantage on the job market earned by a foreign degree. A degree from abroad from any university implicitly guaranteed that the holder was (at least) bilingual, skilled in crosscultural communication, and well-prepared to work in an international environment. These qualities were once a rarity and could command a salary that justified the cost of going overseas. Today these skills are more common and simply expected by many employers. As a result, an overseas degree is much less likely to guarantee the fantastic remuneration of yesteryear.

The ever-increasing cost of studying abroad gives more prospective students pause. When the world economy was growing rapidly, individuals might not have hesitated to invest in an MBA abroad (one of the most expensive graduate degrees, after medicine) that may have represented an investment of anywhere from U.S. $\$ 60$ to U.S. $\$ 100,000$. When there was literally a world of opportunities available upon graduation, the investment could be recovered within a few years. Static or depressed economies in Asia and Latin America no longer offer the same return. This uncertainty has led to the underutilization of government-subsidized loans, in countries like Chile, designed to encourage people to earn graduate degrees abroad; the risk and scale of the debt to be incurred are both too high. 
In fact, individuals now have to wonder whether they can recover their investment and even whether they will find a job after graduation at all. The concern about future opportunities on the job market now motivates people to consider studying part time at one of the betterquality programs at home while continuing to work.

\section{Conclusion}

Students will most certainly continue to go abroad, but more out of preference than necessity or the promise of fantastic salaries. While going abroad might once have been the only way for many talented young people to get a high-quality education, this is no longer the case. Likewise, an international degree no longer guarantees significant financial rewards, let alone a job. But much as on-line education has not eliminated the desire for a classroom experience, an education at home that meets international standards does not offer the same experience as studying in another country. The numbers of people moving about the planet will not be as grand as they once were, but the migrations will continue. Visa processing, prejudice, and, perhaps most important, economic conditions will determine which countries will send students and which countries will benefit by receiving them.

\section{Japan and Transnational Higher Education}

\section{Fujio Ohmori}

Fujio Ohmori is a professor at the Research Center for Higher Education, Kumamoto University. Address: 2-40-1 Kurokami, Kumamoto-shi, 860-8555 Japan. E-mail: f-ohmori@ge.kumamoto-u.ac.jp.

\footnotetext{
A s early as this year, the Japanese government is expected to implement new policies to recognize transnational higher education both domestically and internationally. On March 29, 2004, the Ministry of Education published its study group's report on quality assurance of transnational higher education. The group, consisting of experts and stakeholders in higher education, recommended that the ministry radically change its regulatory framework for transnational provision.

The current framework is said to be based on the "territorial principle." Foreign institutions' branch campuses on Japanese soil, including those accredited in their countries of origin, are not recognized as higher education institutions in Japan unless authorized by the minister as universities or colleges under Japanese law. Similarly, Japanese institutions' offshore programs in other countries are not recognized as part of Japanese higher education, and the ministry's view has been
}

that it is up to a host country's authorities whether or not to recognize the programs.

The current regimen may have been a reasonable part of the national education system in the modern world where sovereign nation states control domestic affairs including education. However, current postmodern trends-including globalization and marketization-are pressuring the Japanese system to change itself.

\section{Foreign Branch Campuses}

Although no official statistics exist on foreign branch campuses in Japan, there were probably around 40 American branches in the early 1990s. Most of them have shut down, and only a handful have survived. The largest one is Temple University Japan (TUJ) that started to operate in 1982 - earlier than any other branch. In addition, quite a few institutions in China, Australia, and other countries have branch campuses in Japan.

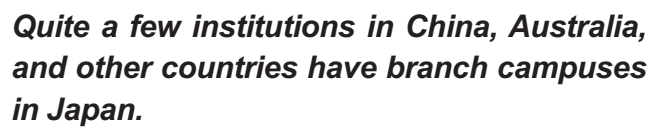
and other countries have branch campuses in Japan.

The branch campuses of foreign institutions are free to provide educational services without having official recognition of the Japanese authorities as part of the country's higher education system. To be recognized under the current system, those branch campuses need to reestablish themselves as universities or colleges under Japanese law in accordance with the standards and criteria set for local universities and colleges. None of the branches have pursued that course. Therefore, for example, credits acquired at Temple University Japan are not transferable to Japanese institutions, while those acquired at Temple University's home campus (TU) are.

Once the policy recommendations in the study group's report are implemented, the above distinction between Temple University and its branch campus in Japan will be eliminated. Under the new regime, foreign institutions' branch campuses in Japan that satisfy certain conditions will be recognized in the same way as their programs in their countries of origin. These conditions will not require matching Japanese quality standards but rather proving the programs are recognized as bona fide higher education in their countries of origin. In short, this new policy will recognize higher education services provided in Japan by established foreign institutions.

Apparently the World Trade Organization General Agreement on Trade in Services negotiations have revitalized the issue of American branch campuses, and 